\title{
個別認証技術を用いた医療用麻薬フェンタニル注射液の院内個別管理
}

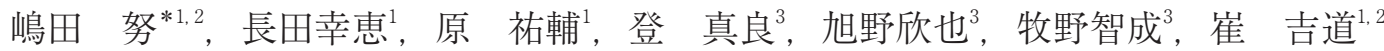 \\ 金沢大学附属病院 薬剂部 ${ }^{1}$ 金沢大学大学院医薬保健学総合研究科 臨床薬理動態学 ${ }^{2}$, シヤチハ夕株式会社 新規事業部 ${ }^{3}$

\section{Appropriate Individual Management of Fentanyl Injection Ampule in Hospital Using Authentication Management Programs}

\author{
Tsutomu Shimada ${ }^{* 1,2}$, Sachie Osada ${ }^{1}$, Yusuke Hara ${ }^{1}$, Masayoshi Nobori ${ }^{3}$, \\ Kinya Asahino, Tomonari Makino ${ }^{3}$ and Yoshimichi Sai ${ }^{1,2}$ \\ Department of Hospital Pharmacy, University Hospital, Kanazawa University ${ }^{1}$, \\ Department of Clinical Pharmacokinetics, Graduate School of Medical Sciences, Kanazawa University ${ }^{2}$, \\ Shachihata Inc. New Business Department ${ }^{3}$ \\ $[$ Received October 11, 2019 ) \\ Accepted March 23, 2020
}

One of the most important operations for pharmacists is drug management. Specifically, pharmacists need to carefully and strictly manage and record narcotic drugs according to the "Narcotics and Psychotropics Control Law", which places both operational and mental burdens on medical staff. In this study, we verified the practicality of the "Shachihata Authentication Management Program” system, which can identify minute non-uniformity in print, for the management of Fentanyl Injection ampules individually and for visualization of them in hospital. To evaluate accuracy of the system, 300 Fentanyl Injection labels were registered and authenticated. Then to verify traceability, each Fentanyl Injection label was registered when stocking in drug safe for narcotic drugs, then they were authenticated when dispatched to wards and operation rooms, when returned to the pharmacy as non-used, and when disposed as used at the pharmacy. As a result of evaluation of accuracy, all 300 ampules were completely identified individually. The traceability of all 189 ampules, which were stocked in drug safe during the study period, was certified individually in hospital. Additionally, the system could record and output the data in the format of narcotic drug accounts, and revealed a stagnation of ampules in drug safe in the operation room. Furthermore, the time required to register or authenticate per one ampule was about 10 seconds. The results indicate that the system realized the traceability of Fentanyl Injection individually in real-time in hospital, suggesting that the system contributes to appropriate individual management for strictly managed drugs without operational and mental pressure.

Key words — Fentanyl Injection ampule, print identification, authentication, traceability

\section{緒 言}

麻薬，向精神薬，覚せい剤原料，特定生物由来 製品，毒薬および劇薬等は法律による規制の下に 保管場所や取り扱い, 記録, 廃棄方法などが㛜し く管理されている. 特に麻薬および向精神薬は, 濫用による保健衛生上の危害を防止し，もって公 共の福祉の増進を図ることを目的に「麻薬及び向 精神薬取締法」が制定されており，医療施設内外
で管理徹底が図られている.医療施設においては, (1)卸販売業者との譲渡証および譲受証の受け渡 し, (2)麻薬施用時の麻薬の品名および数量並びに 施用または交付の年月日の記載, (3)麻薬廃棄時の 麻薬の品名および数量並びに廃棄方法の都道府県 知事への届出など, 多様な対応が必要とされてい る。そのため医療スタッフは, 上記項目に対して 肃々と対応しているが, 多忙な日常業務中の業務 的・心理的負担になっており, 何らかの対応が望

\footnotetext{
*テ920-8641＼cjkstart石川県金沢市宝町13-1
} 
まれている.

一般的に物質の個体識別には, 対象物にバー コードや radio frequency identifier（RFID）などの 識別夕グを取り付ける方法がある.バーコードは, 医薬品にかかわらず幅広い商品に適用されてお り，沉用性が非常に高い一方で，印刷するために は商品自体にある程度の大きさが必要であるこ と, またシール等で貼り付ける場合には外れてし まうなどの短所もある。また，RFID は入退場管 理システムや小売業者による商品管理等に使用さ れ，個別認証としての有用性は非常に高い一方, タグ自体にコストがかかること，後付する必要が あること, 夕グの読み取り機器が必要であること などの短所もある。医薬品業界における一般的な 管理方法としては, 医療用医薬品の取り違え事故 の防止やトレーサビリティ確保のために調剤包装 単位, 販売包装単位および元梱包装単位ごとに定 められたバーコード表示がされている（表 1). ${ }^{1)}$ 2021 年 4 月以降は注射薬 ·内服薬 - 外用薬の販売 包装単位および元梱包装単位における商品コード, 有効期限，製品番号または製造記号表示の必須化 が決定している. ${ }^{23} 2018$ 年 10 月の第 7 回医薬品医 療機器制度部会においては「運用のメリットやコス
トを考慮して」との但し書きがあるものの, 調剤包 装単位において標準化規格に基づくバーコードを 表示することを法令上適する方向性で検討されて いる. ${ }^{4)}$ 米国の Food and Drug Administration（FDA） は 2013 年 11 月 27 日に「医薬品サプライチェー ン安全保障法（Drug Supply Chain Security Act）」 が成立し， 2023 年 11 月からは調剤包装単位のト レーサビリティ管理が発効されるなど（https:// www.fda.gov/drugs/drug-supply-chain-security-actdscsa/drug-supply-chain-security-act-law-and-policies, 2019 年 10 月 8 日), 世界レベルで調剂包装単位 でのデー夕登録管理が必須化されていくことは明 白であるが, 高精度でかつ低コストを備える方法 については確立したものはない.

我々はこれまでにバーコードや RFID などの識別 タグを使わず，製品ラベル等の印刷そのもので製 品を個体識別できる技術, Shachihata authentication management programs（SAMP）を利用した薬哓 管理システムを構築してきた（特許出願中）. SAMP は印刷時に偶然生成される（人為的に制御 することが難しい）微細な色の濃淡や紋様を光学 的に読み取って認証に利用する「人工物メトリク ス (artifact-metrics $) 」 の 1$ 種である. ${ }^{5)}$ 今回我々は,

表 1 医療用医薬品のバーコード表示の対象（医薬品医療機器等安全性情報 No.337 より抜粋）

\begin{tabular}{|c|c|c|c|c|c|c|c|c|c|c|}
\hline \multirow[t]{2}{*}{ 医療用医薬品の種類 } & \multicolumn{3}{|c|}{$\begin{array}{l}\text { I ）調剂包装単位 } \\
\text { PTP シート、バイアル等 }\end{array}$} & \multicolumn{3}{|c|}{$\begin{array}{l}\text { II）販売包装単位 } \\
\text { PTP シートを } 10 \text { 枚収納 } \\
\text { した箱等 }\end{array}$} & \multicolumn{4}{|c|}{ III）元梱包装単位 } \\
\hline & $\begin{array}{l}\text { 商品 } \\
\text { コード }\end{array}$ & $\begin{array}{l}\text { 有効 } \\
\text { 期限 }\end{array}$ & $\begin{array}{l}\text { 製造 } \\
\text { 番号 } \\
\text { 又は } \\
\text { 製造 } \\
\text { 記号 }\end{array}$ & $\begin{array}{l}\text { 商品 } \\
\text { コード }\end{array}$ & $\begin{array}{l}\text { 有効 } \\
\text { 期限 }\end{array}$ & $\begin{array}{l}\text { 製造 } \\
\text { 番号 } \\
\text { 又は } \\
\text { 製造 } \\
\text { 記号 }\end{array}$ & 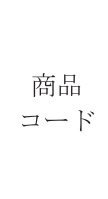 & $\begin{array}{l}\text { 有効 } \\
\text { 期限 }\end{array}$ & $\begin{array}{l}\text { 製造 } \\
\text { 番号 } \\
\text { 又は } \\
\text { 製造 } \\
\text { 記号 }\end{array}$ & 数量 \\
\hline (1)特定生物由来製品 & (0) & ( ) & (0) & (0) & (0) & (0) & (0) & (0) & (0) & (0) \\
\hline (2)生物由来製品 & (0) & $\bigcirc$ & 0 & (?) & (0) & () & () & () & () & (0) \\
\hline (3)注射薬 & () & $\bigcirc$ & 0 & () & (0) & (○) & (0) $*$ & () * & (○) & (0) \\
\hline (4)内用薬 & (0) & $\bigcirc$ & 0 & (0) & (0) & () * & (0) * & () * & (0) & (0) \\
\hline (5)外用薬 & () & 0 & 0 & () & (0* & ( $)^{*}$ & () * & ( ${ }^{*}$ & (○) & ( $)^{*}$ \\
\hline
\end{tabular}

注 1:「@」は必ず表示するもの（必須表示）、「○」は必ずしも表示しなくて差し支えないもの（任意表示）

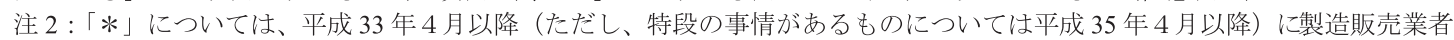
から出荷されるものに必ずバーコード表示 
法令により医薬品管理が厳しく定められている医 療用麻薬の 1 つであるフェンタニル注射液 $0.5 \mathrm{mg}$ 「ヤンセン」(一般名：フェンタニルクエン酸塩注 射液）(フェンタニル注射液）を選択し，薬剤に (1) SAMP を適用した場合の認証精度の検証並びに, (2)薬剤管理システムを用いた院内トレーサビリ ティ確保の検証を実施した。

\section{方法}

\section{SAMP システム}

SAMP システムは図1のように画像取得部, デー 夕生成部，照合部およびデータベースから構成さ れており，登録フェーズ・認証フェーズを経て結 果が出力される，登録フェーズでは，登録時に取 得した印刷物の撮像（登録）原画像を専用アルゴ リズムで処理を行い，印刷時に偶然生じる微細な 色の濃淡であるランダムパターンから特徴量を求 める。その特徴量の上位 250 点の箇所を特徴点と し，登録デー夕を生成，データベースに登録する。 認証フェーズでは，登録フェーズと同様に，認証 時に取得した印刷物の撮像（認証）原画像から特 徵点を求め, 照合デー夕を作成する。

個別認証原理としては，登録データと照合デー 夕の特徴点を照合して, 特徵点の一致数が一定数 以上（闇值以上）であれば，同一製品から取得さ れた原画像である，すなわち同一個体であると判 定する.

今回用いた撮像装置（図 2）は，対象を撮像す るカメラユニットと，アンプルを手動で回転可能
に保持するユニットを有している。 カメラユニッ 卜は内部に照明用光源の LED が設けられ，また， 撮像対象に向かって径が小さくなる絞り形状をし たフードを備えており，外部光を遮光して照明し ながら対象を撮像することにより光環境による影 響を受けにくくなっている。 また，保持ユニット は回転される際にアンプル本体に生じ得る上下 (鉛直) 方向のブレおよび，左右（水平）方向の ブレについて抑制され，さらにカメラユニット先 端からアンプルまでの距離は一定となるように固 定している。ソフトウェアとしては，画面にラべ ルの読み取り位置をガイド表示し，それにラベル を合わせることで，トリガが発生し，自動的に シャッターが切られるようにしている，以上によ

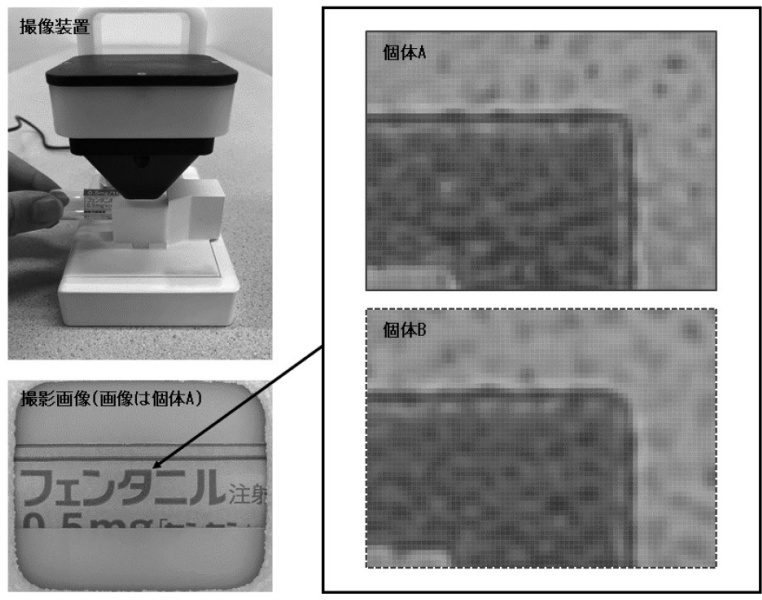

図 2 撮像装置にて撮像されたフェンタニル注射液 の製品ラベル画像

撮像装置（左上）にて撮像したフェンタニル注射液の個体 $\mathrm{A}$ と個体 B の製品ラベルを拡大比較すると色ムラの出現位置が 異なる。

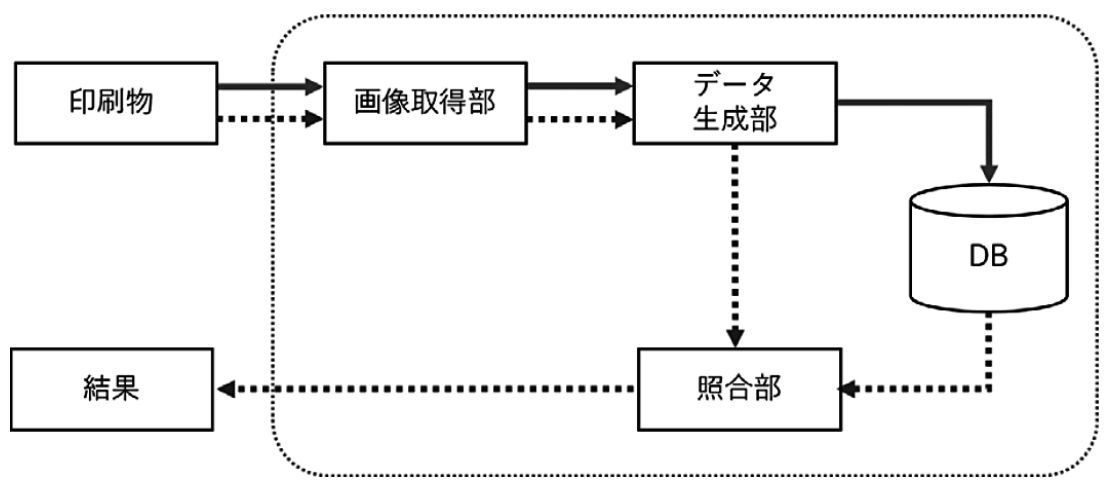

図 1 SAMP システムの基本構成 ーが登録フェーズ，…が認証フェーズを示す。 
り，フェンタニル注射液に貼付されたラベルから 特徵点を精度よく認識できる良好な原画像を取得 することが可能な装置である.

本研究では, 2 名の協力学生により撮像が実施 された。

なお，撮像装置を用いて異なるフェンタニル注 射液 2 個体の製品ラベルをそれぞれ撮像し，拡大 したものを図 2 に示した.

\section{SAMP 認証精度の評価方法}

認証精度の評価方法に関して評価方法や評価指 標を公表している人工物メトリクス・システムは 少ないが，バイオメトリクス・システムの認証精 度の評価指標を適用する手法は一般的になりつつ ある。例として，基材にランダムに分散した磁性 ファイバの磁気パターンを用いた人工物メトリク ス・システムにおいて，バイオメトリクス・シス テムの認証精度の評価指標である false rejection rate（FRR）と false acceptance rate（FAR）を用 いてシステムの認証精度の評価結果が示されてい る. ${ }^{6}$ FRR はシステムが受理すべき人工物を誤っ て拒否する確率（誤拒否率)，FAR はシステムが 拒否すべき人工物を誤って受理する確率であり (誤受理率)，一般的に両者はトレードオフの関係 にあり，一方が減少すれば他方は増大する。 そこ で通常は, 照合判定の適用する対象で損失が最も 小さくなるよう真偽の判定間值を設定する．FRR と FAR の双方が $0 \%$ となる判定閾值が存在すれ ば完全な真偽判定ができることになり，そのよう な閾值の範囲が広いほど安定した判定性能を持っ ていると言える. ${ }^{7}$

本臨床研究では, 撮像装置を用いて 300 本の フェンタニル注射液の製品ラベルを撮像し，登録 データを生成した。次に，同じ印刷部分を同様に 撮像し，登録デー夕と生成した照合データでの照 合を実施し，認証精度を検証した。

\section{3. 院内におけるフェンタニル注射液のトレーサ ビリティ確保の検証}

2017 年 5 月 15 日〜 2 月 2 日の 19 日間において, 院内におけるフェンタニル注射液のトレーサビリ ティ確保の検証を目的に, (1)薬剂部麻薬金庫内に 保管されているフェンタニル注射液アンプルのラ ベルの登録，(2)フェンタニル注射液が薬剤部から 手術室・各病棟へ払い出される際の認証抢よび, (3)フェンタニル注射液が薬剤部に未使用で返却, もしくは使用済みで返却・廃棄される際の認証を 実施した，次に，薬剤管理システムにて得られた 受払い履歴から,フェンタニル注射液の調剤包装 単位でのトレーサビリティ確保の検証, 管理簿およ び院内に打ける流通経路や分配状況のイメージの 出力を行った. なお, 本臨床研究は金沢大学医学 倫理審査委員会の承認を得（承認番号 2015-258）, 「人を対象とする医学系研究に関する倫理指針」 に従い研究を推進した。

\section{結果}

\section{1. 認証精度の検証}

フェンタニル注射液 300 本の認証精度の結果を 表 2 に示した。同一薬剤の登録デー夕と照合デー 夕の組み合わせは 300 通りあり, 特徵点の一致数 の平均值は 250 点中 163.8 点, 最小值は 123 点で あった，一方，別物薬剤の登録デー夕と照合デー 夕の組み合わせは 89,700 通りあり, 特徵点の一 致数の平均值は 30.4 点, 最大值は 64 点であった. 横軸に判定閾値（特徵点の一致数）をとり, FRR と FAR を任意の闇值についてプロットすると， FRR，FAR の双方が $0 \%$ となる閾值が広く存在す ることが示され (図 3)，300 本すべてのフェン タニル注射液を個体識別できることが示された。

表 2 総 250 点の特徴点の一致数の統計データ

\begin{tabular}{|c|c|c|c|c|c|}
\hline & 平均值 & 標準偏差 & 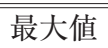 & \begin{tabular}{c|} 
最小值 \\
\end{tabular} & 中央值 \\
\hline 同一個体の画像同士 & 163.8 & 10.7 & 187 & 123 & 165 \\
\hline 別個体の画像同士 & 30.4 & 5.1 & 64 & 11 & 30 \\
\hline
\end{tabular}

同一個体の画像同士の組み合せは 300 通り, 別個体の画像同士の組み合わせは 89,700 通り. 各数字は総点数 250 点中の一致数を表している. 


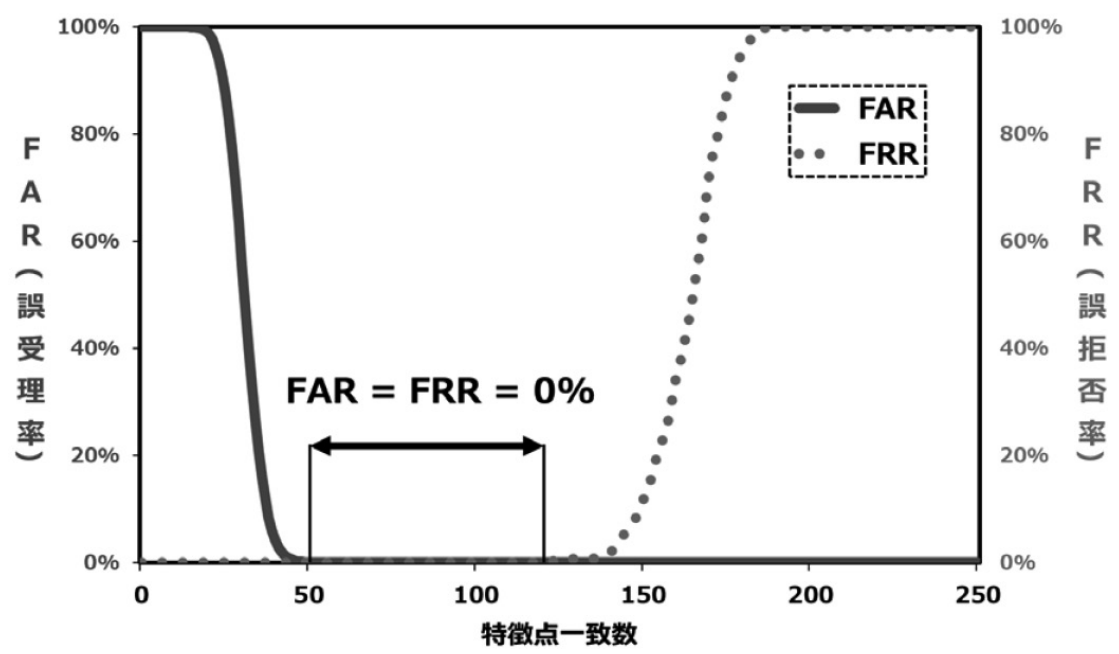

図 3 FAR (誤受理率) 曲線と FRR（誤拒否率）曲線 300 本のフェンタニル注射液を用い, 総当りで認証精度を検証した結果 FAR と FRR 双方が $0 \%$ になる判定閾值の存在を確認できる. FAR: false acceptance rate, FRR: false rejection rate.

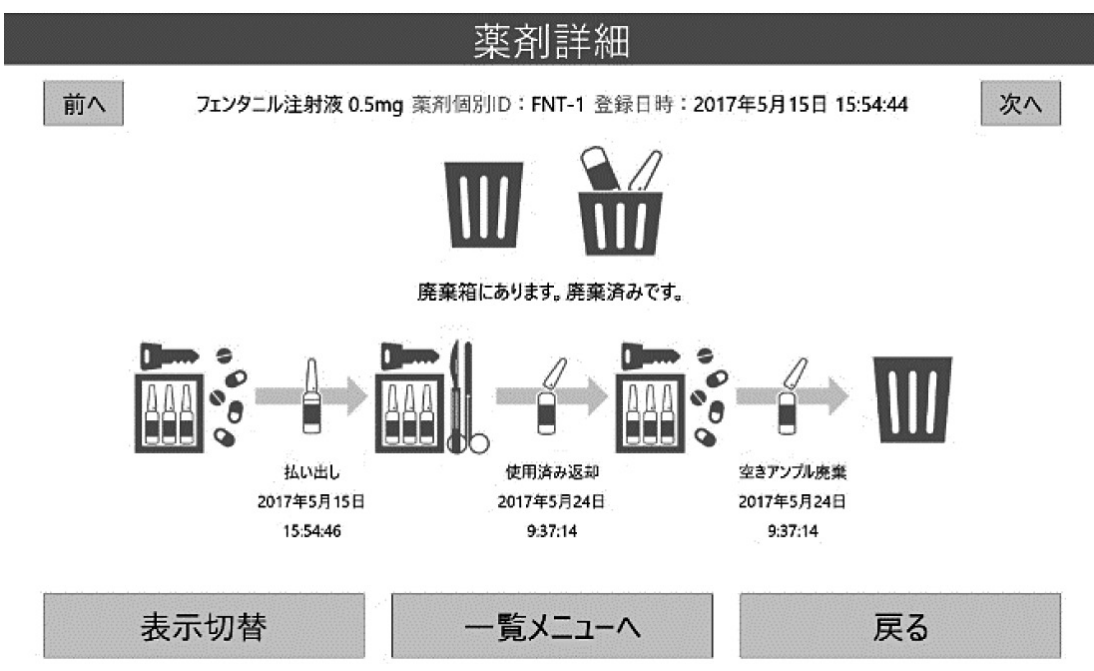

図 4 フェンタニル注射液個体番号 1 の院内流通経路

調剤包装単位でトレーサビリティの確認が可能である. 個体番号 1 は 5 月 15 日に薬剂部麻薬 金庫から手術室に払い出され，5月 24 日に使用済みで返却，廃棄されたことが確認できる.

\section{2. 院内トレーサビリティ確保の検証}

研究期間中に薬剤管理システムに登録された フェンタニル注射液の本数は 189 本で, 薬剤部か ら手術室および各病棟へ払出し，手術室および各 病棟から薬剤部へ返却する際に撮像・認証した回 数は延べ 347 回であった。期間中に個体識別を 誤ったことによるフェンタニル注射液の入れ違い はなく，189本すべて個別に流通経路および所在 を確認できた。最終的に，手術室および各病棟か ら使用済みで薬剤部に返却された本数はそれぞれ 102 本と 36 本であった。 また，手術室および各 病棟に払い出されて未返却のものはそれぞれ 43
本と 3 本であり, 薬棛部麻薬金庫から一度も払い 出されていないものは 5 本であった. なお, トレー サビリティ確保の検証中に打ける 1 本あたりの撮 像・登録・認証にかかる時間は 10 数秒であり, オペレータ間で大きな差はなかった.

フェンタニル注射液の薬剤部麻薬金庫内での保 管時, 手術室や各病棟への払出し時, および未使 用もしくは使用済みでの返却・廃棄時に撮像した 対象薬剤全個体の院内流通経路から個々の薬剤の 移動経路（トレーサビリティ）や現在の所在地が イメージ図として可視化された（図4）。また， 部署間の移動本数の集計結果からは，各部署にお 


\section{所在情報}

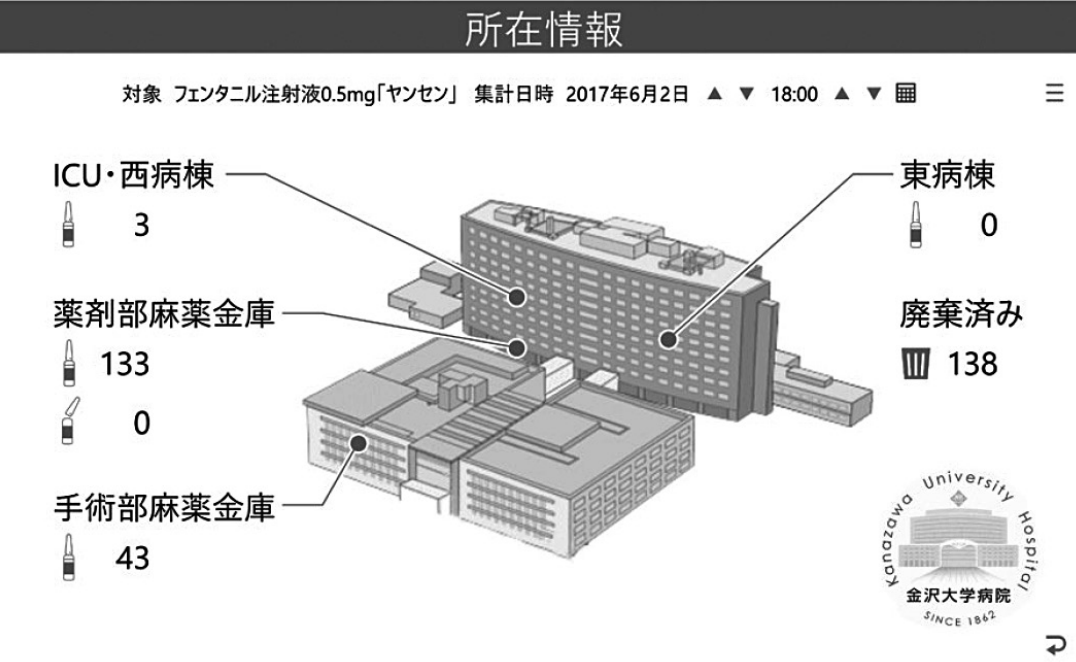

図 5 リアルタイムなフェンタニル注射液の院内分配状況

薬剂管理システムの所在情報機能により，登録済みのフェンタニル注射液の所在をリアル タイムに確認できる。図は 2019 年 6 月 2 日 18 時時点の所在情報.

\section{麻薬帳簿}

\begin{tabular}{|c|c|c|c|c|c|c|}
\hline 日付 & 受入数 & 抎出数 & 残高 & 払出先 & 受抬 $1 D$ & 满考 \\
\hline 2017年5月15日 & 220 & & 220 & 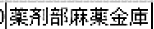 & -- & 在㢆登䟿 \\
\hline 2017年5月 $15 \mathrm{H}$ & & 80 & 140 & 手術部麻䔳余席 & 2017051501 & \\
\hline 2017年5月15日 & & 1 & 139 & $1 \mathrm{CU}$ & 2017051803 & 患者A \\
\hline 2017年5月16日 & 75 & & 214 & 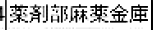 & $\cdots$ & 在㡷登緑 \\
\hline 2017年5月16日 & 9 & & 223 & 手術部麻䕓金麿 & 2017051501 & 未使用返却 \\
\hline 2017年5月 16日 & & 5 & 218 & 手術部麻䙹金庫 & 2017051602 & \\
\hline 2017年5月16日 & & 9 & 209 & 手術部麻蕜金庫 & 2017051601 & \\
\hline 2017年5月 $16 \square$ & & 1 & 208 & $81 \mathrm{CU}$ & 2017051603 & 恚者B \\
\hline 2017年5月16日 & & 1 & 207 & $1 \mathrm{CU}$ & 2017051604 & 必者C \\
\hline 2017年5月16日 & & 1 & 206 & $1 \mathrm{CU}$ & 2017051605 & 患者D \\
\hline 2017年5月17日 & 1 & & 207 & $1 \mathrm{CU}$ & 2017051603 & 未使用返却 \\
\hline 2017年5月17日 & & 3 & 204 & $4 \mathrm{CU}$ & 2017051702 & 忠者 $\mathrm{E}$ \\
\hline 2017年5月17日 & & 9 & 195 & 手術部庥璓金庫 & 2017051703 & \\
\hline 2017年5月17日 & & 1 & 194 & $1 \mathrm{CU}$ & 2017052204 & 患者F \\
\hline 2017 年5月 $18 \mathrm{H}$ & & 1 & 193 & $1 \mathrm{CU}$ & 2017051801 & 虫考 $G$ \\
\hline
\end{tabular}

図 6 薬剂管理システムの帳票作成機能により作成した麻薬帳簿出力 (イメージ) 2019 年 5 月 15 日〜 5 月 18 日の間に登録・認証したフェンタニル注射液の麻薬帳簿の出力 イメージ．登録・認証するだけで麻薬帳簿（イメージ）の作成が可能である.

いて未使用で返却される本数や，手術部の麻薬金 庫にストックされているものが滞留していること も明らかとなった。ささらに, 本システムのアウト プット情報として，リアルタイムでの病院全体の なかにおける薬剤の分配状況を把握（図 5)，お よび帳票作成機能により義務付けられた麻薬帳簿 のイメージを作成することができた（図 6).

\section{考察}

本臨床研究では, 印刷の微細な違いを利用して,
製品を個体識別できるSAMPを用いて麻薬注射 剂であるフェンタニル注射液の認証精度について 検証した，FRR，FAR 双方が $0 \%$ になる判定閾值 が存在することから調剤包装単位での個体識別が 可能であることが示された。

次に，SAMPを利用した薬剤管理システムを用 いて，フェンタニル注射液を(1)薬剂部麻薬金庫の 保管時の登録, (2)手術室や病棟への払出し時の認 証，(3)未使用返品または使用済みアンプルの返 却・廃棄時の認証によって, 調剤包装単位として リアルタイムな院内トレーサビリティの実現を示 
すことができた，本機能を用いることにより，院 内から出所不明な使用済みのアンプルが見つかっ たとしても, ラベルを撮像するだけでいつ, 誰が, どの場所に払い出したものか特定することが可能 となった。ささらに帳票作成機能により法的に作成 が義務付けられている帳簿のイメージ出力や院内 における流通経路や分配状況のイメージ出力がで きた，以上の結果から，本システムが臨床現場の 医薬品管理に扔いても実装可能であることが示唆 された。

これまでにバーコードや RFID 等の様々な認証技 術がすでに開発・実用化されてきているが，SAMP がほかの技術と比較し有用な点としては(1)特別な 印刷や識別夕グの付加は必要なく現状の製品のま まで対応可能, (2)個別のデータは数十キロバイト と保存データ容量が抑えられクラウドなどによる データ共有が可能，(3)コピー機で複製した印刷も 識別可能（高い耐偽造性能），(4)日常で考えられ るレベルの摩耗・室内経時劣化・アルコール拭き 取り等にも耐えうる，(5)元梱包装単位や販売包装 単位レベルでなく調剤包装単位であるアンプル 個々単位で識別できる，6-般的に難しいとされ る曲面のラベルにおいて認証が可能である，など がこれまでの検討で確認されており，ほかの剤形 や医薬品以外への実用性も高いと思われる.

一方, 現時点におけるSAMPの欠点としては, (1)対象とする薬剤の形状に合わせた撮影環境およ び撮像装置を作成する必要がある, (2)アンプルで あれば 1 本ずつ，錠剤であれば 1 錠ずつ撮像する 必要があり, 複数同時に撮像ができない, (3)ハン ディタイプとして持ち運ぶには大きい，などが挙 げられる，技術革新が目覚しい現在においてはそ う遠くない未来において上記問題は解決できると 思われ, 今後は, カメラメーカーやレンズメーカー, 機器メーカーなどと協力することにより医療又 タッフがルーチンワークのなかで使用しやすい形 状やシステムの開発が必要であると考えられる.

医療機関における調剤包装単位のバーコード利 用状況について幾つか報告がある。日本病院薬剤 師会が実施している「病院薬剂部門の現状調査」 によると, 調剤包装単位のバーコード利用は年々 増加しており 500 床以上の医療機関ではその利用
率は 2014 2016 年の 2 年の間に 3 倍以上と急増 している. ${ }^{8-10)}$ また，日本ユーザービリティ医療情 報化推進協議会（JUMP） が, 4,101 施設の病院 を調査した結果, 調剤業務において 49.4\%の施設 がGS1 バーコードを利用しており，用途として 混合調製や処方監查に使用していることを報告し ている. ${ }^{11)}$ 保健薬局を対象とした日本保健薬局協 会と製剂機械技術学会のアンケート調查におい て, 調剂包装単位での GS1 バーコード利用率は $88.1 \%$ であり, 用途としてピッキングや監査, ピッ キングマシンへの補充時に使用しているとの報告 もある. ${ }^{12)}$ 現状のバーコードリーダ技術を用いた 調剂包装単位での管理は, 取り間違い対策や効率 化としてメリットがあり, 今後も拡張し続けるこ とは明白である。 SAMPを既存のバーコードリー ダ内に組み込むことによってすでに実施している ルーチンワークのなかで, 上記取り間違い対策や 効率化のみならず，アンプルや錠剤 1 錠ずつの単 位の医薬品管理やトレーサビリティなどを管理す ることが可能であると考えられる。

本研究では, 医薬品を調剤包装単位で登録する ことにより，納入後に扔ける院内トレーサビリ ティの実用化を示すことができた．今後の展望と しては，本システムを院内だけで完結するのでは なく, 医薬品を取り扱う業界全体で活用すること により, より良いトレーサビリティの構築につな がると考えられる。すでに各製薬メーカーの製造 ラインで品質管理のために調剤包装単位（PTP シートは錠剤単位)で検査画像が取得されており, SAMPをカメラ内に導入することにより同時に特 徵点の登録ができる。また, 調剤包装単位は製造 ラインにて販売包装単位, さらに元梱包装単位に まとめられるが，その際印刷される GS1 コード と SAMP 登録デー夕を紐付けすることで, 全流 通のトレーサビリティを管理することも可能であ る. 規制当局, 製薬業界, 卸業界, 医療 - 介護機 関など医療にかかわる様々な業種が連携すること が重要となるが, 本システムを既存の医薬品管理 システム内に導入することにより製造ラインから 患者が使用するまでの一連の医薬品流通のトレー サビリティ確保を可能とすることが期待でき, 回 収ロットの追跡や製品の取り違い防止, 偽造薬混 
入や不正取引などにも対応が可能となると思われ る. 現在, 本 SAMP 以外にも様々な特徴を備え た個別認証技術が開発されているが，それら認証 技術の特徴と internet of things（IoT）技術をうま く組み合わせることにより, 堅牢性の高い医薬品 流通管理を実施することが医薬品の適正使用のた めに重要であると考えられる，今後は，本システ ムのデバイスや仕組みをさらに発展させ，医薬品 のトレーサビリティに耐えうるシステム改良を継 続していく予定である.

\section{利益相反}

崔 吉道 (シヤチハ夕株式会社), 嶋田 努 (シ ヤチハ夕株式会社).

\section{引用文献}

1）平成18年 9 月15日, 薬食安発0915001号, 医療用 医薬品へのバーコード表示の実施について, 別 紙 医療用医薬品へのバーコード表示の実施要 項（厚生労働省医薬食品安全対策課長）.

2）平成28年 8 月 30 日, 医政経発0830第 1 号・薬生 安発0830第 1 号・薬生監麻発0830第 1 号, 「医療 用医薬品へのバーコード表示の実施要項」の一 部改正について（厚生労働省医政局経済課長, 医薬・生活衛生局安全対策課長, 医薬・生活衛
生局監視指導・麻薬対策課長連名通知).

3）厚生労働省医薬・生活衛生局, 医薬品医療機器 等安全性情報, No.337, 2016年10月。

4）平成30年10月18日, 第 7 回医薬品医療機器制度 部会 資料 1 , 迅速なアクセス・安全対策の充 実等, 医薬品・医療機器のトレーサビリティの 向上, pp11-12.

5）松本 勉, 人工物メトリクス入門, 日本印刷学会 誌, 2012, 49, 185-189.

6）松本弘之, 宇根正志, 松本 勉, 岩下直行, 菅原 嗣高, 人工物メトリクスの評価における現状と 課題, 金融研究, 2004, 23, 61-140.

7）伊藤健介, 左右田宏之, 井原富士夫, 木村哲也, 布施マリオ, 紙ドキュメントのセキュリティ, 富士 ゼロックステクニカルレポート, 2005, 15, 36-37.

8）平成26年度「病院薬剂部の現状調査」集計結果 報告, 日本病院薬剤師会雑誌, 2015, 51, 613-683.

9）平成27年度「病院薬剤部の現状調查」集計結果 報告, 日本病院薬剤師会雑誌, 2016, 52, 761-832.

10）平成28年度「病院薬剂部の現状調査」集計結果 報告, 日本病院薬剤師会雑誌, 2017, 53, 751-819.

11）大道道大, “UDI\&UI利活用で進めるこれからの デジタル医療”、医療製品識別とトレーサビリ ティ推進協議会, 東京, 2018, pp87-93.

12）山北勝夫, 菅野敦之, 大道 久, 根東義明, 梅里 良正, 保健薬局に扮ける新バーコード (GS1 DataBar）の活用と課題, 日本医療 - 病院管理学 会誌, 2013, 50, 189-197. 